\title{
Environment Pollution- Macro and Micro Effects
}

\author{
PK Keshap* \\ Associate Professor to MBA, PGPM, Synetic Business School, India
}

Submission: December 15, 2017; Published: December 21, 2017

*Corresponding author: : PK Keshap, Associate Professor to MBA, PGPM, Synetic Business School, Founding Member of Education Consultants of India, India, Email: mpi678@gmail.com

\section{Mini Review}

Environment pollution is the result of careless attitude of Governments, rulers and individuals for centuries. Materialistic attitude is greatly responsible for environment pollution that is causing reduction in the immunity of human beings and causing the deadly diseases like cancer, asthma, weak bone morrow and poor immunity among humans, animals and other living habitat especially trees.

\section{Macro Pollution - A Perspective}

When environment cannot destroy is element without harming or damaging itself is referred to environment pollution. Alternatively, it can be said that nature is not capable to decompose an element that has affected it in an unnatural way. The destroying process may vary from some days to thousands of years (as is the case of radioactive pollutants). Environment pollution is a serious problem facing the inhabitants of planet Earth. It is an absolute need for life to exist on the planet as water and air if polluted beyond tolerable limit can cause extinction of inhabitants of planet [1]. Governments and the NGOs should take environment pollution management seriously and cooperate with UNEP (United Nations Environment Program) for improving the air and water pollution globally.

\section{E- Waste - A New Challenge}

UNO (United Nations Organization) released a report that has startling facts. UNO warned that electronic waste generated from mobile phones, laptops, refrigerators, washing machines and other domestic appliances is another threat to the inhabitants of planet earth. The hazardous waste should be recycled effectively is a guideline to the nations globally.

\section{Brief Facts of the report}

a) Worldwide generation of e-waste in 2016, 44.7 million tonnes.

b) Projected clutter of e-waste by 2021, $52.2 \mathrm{~m}$ tonnes (An increase of $7.5 \mathrm{~m}$ tonnes)

c) E-waste recycled in 2016, 20\% of $44.7 \mathrm{~m}$. tonnes.

d) Value of e-waste including gold, \$ $64.6 \mathrm{bn}$
The report further describes that e-waste is equivalent of 4500 Eiffel Towers. Its swelling globally should be restricted by re-cycling. This waste can pose serious risks and threats to human health and environment in coming years was the warning by UNO.

\section{Effects}

\section{Macro Ecosystem}

Environment pollution largely caused by human activities has a negative effect on the eco-system that results in destroying crucial layers of the eco-system and affects the upper layers negatively and drastically. Ecosystem is an interaction of air, water and mineral soil that acts and reacts internally with each other to make a system so that humans, animal and plants may survive on this planet [2].

\section{Micro Ecosystem}

Major pollutions identified are: air pollution, water pollution and soil pollution. Sound pollution and the new entry into pollutants e-waste are also includible in environment pollution.

I. Humans: Humans are affected by pollution resulting from processed foods and pesticides that are consumed by them at day-in and day -out cause diseases like hepatitis, typhoid, and diarrhoea and hormonal disruptions. The extent of air pollution is that an expert opined regarding the quality of air in a capital city of a country: A child born today inhales smoke from this pollution equal to smoking of 20 cigarettes [3]. By the end of the year, the child's lungs will be black with this smoke and the child will become a person with weak immunity attracting general ailments like allergy, cough, nausea etc. at the drop of hat.

II. Animals: Animals are perhaps the worst affected from environmental pollution as acid rains change composition of water in rivers and seas. It makes the water toxic for fishes and polluted ozone atmosphere causes lung problems to all animals. Algae, the essential food of amphibians, becomes toxic by nitrogen and phosphates in water. Eventually, the amphibians and animals are exposed to greater risk to their lives. 
III. Plants and trees: Ozone layer of the lower atmosphere blocks the plant and trees respiration as harmful pollutants in acid rains are absorbed by them from water and soil. Acid rain affects animals, plants and trees as the natural environment is modified and made unfit for their consumption.

\section{Conclusion}

Arise, awake and act to prevent macro and micro level damage and harm to our planet Earth through environmental pollution.

\section{References}

1. https://en.wikipedia.org/United_Nations_Environment_Programme.

2. https://www.conserve-energy-future.com/causes -and-effects-ofenvironmental-pollution.php

3. UNO's report on e-Waste released in Geneva in December, 2017.
Your next submission with Juniper Publishers will reach you the below assets

- Quality Editorial service

- Swift Peer Review

- Reprints availability

- E-prints Service

- Manuscript Podcast for convenient understanding

- Global attainment for your research

- Manuscript accessibility in different formats

(Pdf, E-pub, Full Text, Audio)

- Unceasing customer service

Track the below URL for one-step submission https://juniperpublishers.com/online-submission.php 